he had his own inimitable style, but his pleasure in the game was always fresh. He had a fund of stories about his own experiences, mainly in connection with his excavations at Kish, and his laughter was of that spontaneous kind which infects all who hear it. That his life should thus be cut short will be a real grief to his many friends, who remember him for these things."

Langdon's career, which began in surroundings where academic learnings were discouraged and ended in an Oxford Professorship, is hardly less than heroic.

R. Campbell Thompson.

\title{
Hon. Desmond Parsons
}

At Zurich, on 4th July, Desmond Parsons died after suffering for two years from an illness which seemed to have been the outcome of hardships while travelling in China. Though aged only 26, he had made active advances in the study of Chinese civilization which was his chosen work. Having visited places of archæological moment in the provinces of Honan and Shensi, he made a journey to Tunhuang in difficult circumstances, examining the geographical features of the ancient highway to the West along the Kansu corridor. Some misunderstanding by the local authorities led to his arrest, and he was released at Lanchou only after diplomatic intervention. Before that he had managed to take over 120 photographs in the famous Buddhist cave-shrines at Tunhuang, including certain wall-paintings which had not yet been recorded. Copies are preserved in the Courtauld Institute, and in the collections of Harvard University and several American museums.

Possessed of an unusual capacity for observation and of a fine scholarly instinct, he.would doubtless have contributed ably to the Chinese studies he loved. His charming personality and transparent honesty of purpose claimed the admiration of all who knew him.

W. Perceval Yetts. 